\title{
Prostitution as Social Pathology: A Legal and Criminological Perspective
}

\author{
Ermiyani Sagala ${ }^{1}$, Natalia Sihotang ${ }^{2}$, Zulmi Efendi ${ }^{3}$, Arif Febriyana ${ }^{4}$ @ \\ ${ }^{1,2}$ Research Institute for Law, Crime and Society, Semarang, Indonesia \\ ${ }^{3,4}$ Faculty of Law, Universitas Negeri Semarang, Indonesia \\ @penpowae8@gmail.com
}

\begin{abstract}
This research aimed to describe and analyze what are the factors behind a person's choosing to become Commercial Sex Workers (CSWs). In addition, this observation also aims to find out how people's perceptions or views about the existence of these CSWs around the community and their impact as well as what efforts have been made to eradicate this CSW in its shelter. This study used descriptive qualitative method. The object of research is the CSWs and the surrounding community. The sample used was purposive sampling, which is sampling based on specific objectives and considerations. Data collection techniques using interview techniques to informants conducted by non-participant observation which only observes and makes observations and documentation. Whereas to analyze the data used an interactive analysis model from Miles and Huberman namely data collection, data reduction, data presentation and conclusion drawing. The results of the study that the authors found in the field that the dominant factor that causes a person to work as a prostitute are economic factors. Economic factors in this case are difficult to meet their daily needs because there are no jobs that generate enough money to meet their daily needs. In addition to economic factors, there are also other factors such as the difficulty of finding work, low levels of education, income factors become more adequate sex workers to meet the needs and family factors.
\end{abstract}

Keywords: Prostitution; Commercial Sex Workers (CSWs); Criminology; Social Phenomenon; Pathology Social

\section{Introduction}

In the era of modernization and globalization which greatly colors the social life of people both in developed and developing countries, in metropolitan areas and in rural areas, giving birth to various impacts, both positive and negative impacts. The impact of modernization and globalization which is increasingly developing occur in various fields of human life, where the impact is increasingly visible and obvious over time.

The impact of modernization is evident in today's life, such as the increasingly sophisticated technology used in everyday life, both for individual needs and general needs. Individual needs can be seen in the use of telecommunications equipment as a means of communication between individuals, as well as groups.

In addition to technology, developments in modernization are also seen in the social field, this is also seen in the way in which individuals or communities communicate today, people are currently communicating with one another using telecommunications aids contained in one network. This development is very rapid, before people who communicate directly or face to face with the discovery of paper, humans use paper as a way to communicate long distance. Furthermore, with the development of technology, with the invention of the telephone, those separated by distance related to 
each other using telephone media in the presence of radio waves.

Modernization and globalization also affect human life in the form of asek in the way humans meet their needs or economic aspects. Nowadays the people who used to fulfill their daily needs starting from hunting, gathering, farming, raising livestock, trading, until now human or community fulfilling their needs can be inversely proportional to what was previously done, which they previously worked outside at this time humans can meet the necessities of life by working through what he likes, which is increasingly complex in today's modern era. Meeting the needs of his life without hard physical work outside, now humans are becoming increasingly dependent on technology.

Whether it is realized or not, changes in society must occur, although sometimes changes in it are not always striking or very influential on broad life. There are changes that are fast and cover broad aspects, some are very slow. Changes in society can be about social values, social norms, patterns of organizational behavior, the composition of social institutions, layers of society, power and authority, social interaction and so forth (Soekanto, 1994).

Basically, all nations and societies in the world are always involved in the process of modernization, although the speed and direction of change varies from one community to another. Modernization is essentially a process of change or renewal. Renewal covers a very large number of fields, depending on which sector the authorities will prioritize. If individuals or communities are open to new things, then there is a tendency that the modernization process will proceed quickly (Rosana, 2012). Soerjono Soekanto formulated that social change is all changes in social institutions in a society, which affect its social system, including values, attitudes, and behavior patterns among groups in society (Soekanto, 2001).

With the increasingly diverse variety of ways to meet economic needs, some people with social status that are considered to be no longer important in life, they are willing to sell themselves to people who want more satisfaction in intercourse. Those who have an economy or feel unsatisfied choose to hire someone who can satisfy their desires through prostitution. Prostitution in the meaning of light is a prostitute or sex servant or commercial sex worker or also called a seller of sexual services. Meanwhile, according to the term, prostitution itself is referred to as a job by surrendering or selling sexual services in the hope of getting wages or rewards from people who use these sexual services.

Of the majority of prostitutes, most of those who become commercial sex workers are women, the percentage of women compared to men is more dominant. The dominance of women in the prostitution area is currently causing various kinds of unrest in the community, the emergence of negative views towards commercial sex workers in the community can also be an influence on the number or quantity of commercial sex workers. Women who are also individuals with important roles in the community have a very low social status if they enter the world of commercial sex prostitution that provides services to consumers or customers through agency services. Women who, as in the view of the community also have lower power compared to men who have greater or dominant power both in social and physical status biologically, so there will be the possibility of women being the object of violence or even the object of crime committed by men and even women.

Based on the background description of the problem above, on this occasion the author will discuss the problem with the problem formulation as follows:

1. How is the prostitution activity going on in the city of Semarang in the Argorejo or Sunan Kuning localization?

2. What is Indonesian law in responding to this?

3. How can crimes occur in prostitution activities?

\section{Method}

\section{A. Research Types and Approaches}

This study used descriptive qualitative method. Where the object of this research is Commercial Sex Workers and the surrounding community who live in a prostitution environment as objects to strengthen this research. This research is an empirical (holistic / combined) normative legal research, namely the study of legal materials, both primary and secondary legal materials and assessing the legal consequences / impacts.

The type of research in this case study, " $a$ picture of the results of in-depth observations, and complete, so that in the information it conveys appears to be alive as it is and the actors have a place to give their respective roles in this study". 


\section{B. Data Sources}

The source of data in this study is to use secondary data is data from library research where in the secondary data consists of 3 (three) legal materials, namely primary legal materials, secondary legal materials and tertiary legal materials as follows:

1. Primary Legal Material is legal material that is binding in the form of applicable laws and regulations and is related to the issues discussed. Consists of:

a) Criminal Code by R. Soesilo

b) Law No. 21 of 2007 concerning Eradication of Trafficking in Persons

c) Law No. 35 of 2014 concerning child protection

2. Secondary Legal Material is legal material that explains the primary legal entity, where secondary legal material in the form of literature books, websites, and the work of scholars. Consists of:

1) Books:

b) Introduction to Legal Research by Soerjono Soekanto

c) Problems of Law Enforcement and Crime Management Policies by Barda Nawawi

d) Books on Legal Research

e) Books on Normative Legal Research

f) Book - Legal Research Method

g) Documents in the Police.

1) National journals include:

a) Siti Munawaroh, "Pekerja Seks Komersial (PSK) di Wilayah Prambanan, Kabupaten Klaten, Jawa Tengah," (DIMENSIA, Volume 4, No, 2 September 2010)

b) Journal Modernisasi dan Perubahan Sosial, Jurnal TAPIs Vol.7 No.12 January-July 2011, oleh Ellya Rosana.

3. Tertiary Legal Material is legal material as a complement to the two previous legal materials, namely the legal dictionary and the results of interviews or empirical observations as a support to provide a comprehensive picture both normatively and sociologically or empirically.

\section{Data Collection Method}

The technique used in collecting this data is taken from legal materials as normative studies, mostly obtained through legal documents, including legislation, law books, and legal journals.

\section{Data Processing Method}

Data analysis is a process that is never finished. The data analysis process is actually a work to find themes and formulate hypotheses, even though there is actually no definite formula to be used to formulate hypotheses. It's just that the analysis of data themes and hypotheses are further enriched and deepened by combining them with existing data sources.

\section{E. Research location}

The location of research conducted by the author to obtain data sources, namely: Jalan Leddosari Raya, Kalibanteng Kulon, Semarang Barat, Semarang City, Central Java 50145, Sunan Kuning.

\section{Result and Discussion}

\section{A. Overview of Prostitution or Localization}

According to Commemge in Tjahjo Purnomo, prostitution or prostitution is an act of a woman trading or selling her body, which is done to get paid for the men who come to the woman. Kartini Kartono defines prostitution or prostitution as a self-selling event by selling bodies, honor and personality to many people to satisfy their sexual desires in exchange for payment. Whereas Soerjono Soekanto said that prostitution or prostitution is a work that is surrendered to commit sexual acts by getting a wage (Chusnafariha, 2017).

Etymonologically the word prostitution comes from the Latin word "pro-stituere" meaning to allow oneself to commit adultery, commit sexual immorality, sexual immorality, and ethnicity. While the word 'prostitute' refers to an adverb which means WTS or prostitute also known as Wanita Tuna Susila (WTS). Referring to the Big Indonesian Dictionary (KBBI) WTS is a wretch or about selling themselves (prostitution) or a prostitute. Prostitution can also be interpreted as a job that is surrendering or selling services to the public to perform sexual acts by getting rewards in accordance with what was previously promised. Someone who sells sexual services is called WTS, which is now often referred to as Commercial Sex Workers (CSWs) (Siregar, 2015). Based on some of these definitions, the author provides the understanding that prostitution or prostitution is an act in which men or women who peddle themselves or provide services to have sexual relations with the 
opposite sex are carried out to get rewards from what they do.

Furthermore, according to Kartini Kartono (2005) there are a number of people who fall into the category of prostitution, namely:

1. Divorce is the maintenance of an unofficial wife, illicit wife or domestic woman. They live as husband and wife, but without marriage ties.

2. Aunty is a married woman, but still having sex with another man, to fill in the free time and have fun and get other sexual experiences.

3. Bar girls are girls who work as bar waitresses and at the same time are willing to provide sexual services to visitors.

4. Free girls are girls who are still in school or have dropped out of school, dropped out of academic studies or faculties, who have a bad attitude and spread sexual freedom to get sexual satisfaction.

5. Call girls are girls and women who used to make themselves available to be called and employed as prostitutes, through certain channels.

6. Taxi girls, namely call girls who are offered and taken to places of entertainment with the taxis.

7. Hotstes or waitresses are women who disguise the nightlife in a nightclub. In essence, the hostess profession is a form of fine prostitution.

8. This promiscuity is free sex with any man or with many men.

\section{B. Pimps in Prostitution}

Pimps are a profession in society regulated in the Criminal Code and very contrary to decency, mentioned the term pimps which are classified as moral offenses set out in CHAPTER XIV II Book II of the Criminal Code. But the term understanding needs to be interpreted clearly and can be accepted as to why the term pimp includes the crime of decency. The definition of a pimp is a man or woman whose life seems to be financed by a prostitute, who in prostitution helps find subscriptions for the proceeds from which he gets his share and benefits from the work done by prostitutes. What is meant by people who attract profit here is the pimp (Caswanto, 2016).

\section{Factors for Prostitution or Localization}

Several factors cause prostitution as a cause or reason for a woman to enter the world of prostitution. There is also a British social worker said in his book, Women of the Streets, about the individual and social circumstances that can cause a woman to become a prostitute is (Ralph, 1961):

1. Feeling alienated from the association or feeling alienated from the association of life at a certain time in his life.

2. Factors that are active in a state before it is decided to prostitute, in reality this is a direct cause but almost always and only possible due to the situation. Previously it was possible for this to happen.

3. Depending on the woman's personality itself. The causes of this prostitution are (Munawaroh 2010):

1. Low level of people's economic life

2. The many influences of luxury goods that encourage people to own them.

3. Household life that is not harmonious, whether in the field of relationships, economics, or sex that is not satisfactory.

4. Increased pornographic films and VCDs, obscene images in the community where the fans are mostly school teenagers.

Other causes can be seen from endogenous and exogenous factors. Endogenous factors such as large sexual appetite, laziness and a great desire to live luxuriously. Exogenous factors are economic factors, irregular urbanization, inadequate housing conditions and others. The real causes are mental conflicts, unfavorable life situations in childhood and personality patterns that are less mature, coupled with low-level intelligence.

\section{Prostitution Forms}

Prostitution or localization has several forms in operation, there are two forms of prostitution, namely (Kartini, 2005):

1. Registered prostitution (legal), such as the treatment in prostitution is overseen by the deputy control section of the police, which is assisted and cooperates with the social and health departments. In general, they (prostitutes) are localized in one particular area, then the residents must periodically check themselves with the doctor or health worker and get injections and treatment, as a public health and safety measure.

2. Prostitution is not registered (illegal), is people who carry out prostitution in a dark and illegal, both individually and in groups, their actions are not organized and the place is not certain, so that health is very doubtful because it is not necessarily willing to check the health of the doctor . 
Types of prostitution according to the amount, namely:

1. Prostitution that operates individually is a single operator Often referred to as street prostitutes. They usually hang out on the roadside, station and other safe places. These prostitutes carry out their profession in disguise.

2. Prostitution that works with the help of wellorganized organizations and syndicates. So, they do not work alone but are regulated through a work system of an organization. Usually in the form of embroidery houses, bars or casinos.

Types of prostitution according to the classification or localization, namely:

1. Segregation or localization, which is isolated or separated from other population complexes. Such as the localization of Silir in Solo and Dolly Gang in Surabaya. Although this localization is no longer available, prostitutes are still operating, namely on the roadside, hek night and they are lower-class prostitutes who work closely with rickshaw drivers and traders.

2. Call houses, these call houses have special characteristics that only the relevant parties know about. In addition, the activities are more organized and closed.

3. Behind the organization's front or behind respectable businesses (beauty salons, massage parlors, restaurants, internet cafes, dim shops, etc.). Here already have a good and organized network. Not a few involving respected people and the security forces, namely the police.

From the forms of prostitution above prostitution in white and gray circles, this includes prostitution that is not registered (illegal), because it is done secretly and closed there is no interference from the social department and the police.

\section{E. Observation and Research Results}

In the case of prostitution that occurred in Sunan Kuning, there were some cases which were taken from observations in the field which were done by the author. In this case, it turns out that the role of the surrounding environment is very decisive in action or is at the root of the problem in this prostitution case, these roles consist of parents, friends, relatives, girlfriends and neighbors, and in this case we summarize the roles of these roles into written form which can give readers broad insights.

A very crucial role that can be the root of a person can be a prostitute woman that is the role of family or parents. Why is that? This we can see through the conditions in which parents depend their lives on their children, while the child is unable or does not understand about the world of work and these demands sometimes become burdens and responsibilities that must be fulfilled by the child.

The results of our observations on Friday night Saturday, May 3, 2019, 21.00-00.00 WIB in Sunan Kuning. we successfully interviewed a prostitute named Putri Suhartini (her real name) or who was often called Mira (not her real name). The results of our interview are as follows: Mira is 32 years old, she is originally from Semarang, born in Semarang, March 6, 1987, Mira is a widow because her husband died 3 years ago. Mira has a 14-year-old daughter. And this work was done to finance his children who now occupy high school (SMP). The tariff he pegged to each customer is Rp 150,000 $\mathrm{Rp} 200,000$.

Mira is a worker as well as a karaoke keeper she works for. He peddled himself from 22.00 04.00 (dawn) and the rest was used to guard the place while resting there. there are people who wear it they never wear it for a day, except when they come to work when they get their period. he can serve a maximum of 5 people in an overnight time this is due to the condition of his body which makes it impossible to serve more customers. The income that Mira can get can reach Rp. 1,000,000.00 overnight. According to Mira, PSKs in Semarang are mostly migrants from outside the city of Semarang, such as from Garut, Majalaya, Tasik, Cimahi, Padalarang, Ciwidey, Cianjur, Sukabumi, Indramayu, Yogyakarta, Demak. And Sunan Kuning is itself a shelter for CSWs to carry out their work, and the Raids that are carried out in this place are only for raids on drinks and illegal drugs such as drugs, cannabis and so on.

According to him, being a sex worker was indeed a goal, not because of outside factors, but he himself decided to become a prostitute. He went through this work because he was forced to. In addition to economic factors also due to family factors, namely the death of the backbone that makes a living for him. He said that actually in carrying out this work there was a great feeling of fear of sin but it was not uncommon for him to go to worship to be forgiven and get sustenance for his work. Because he knows that life in this world is only temporary. And joking, he believes that every human being will die. One of the interesting things from this interview when we asked his opinion about the FPI (Islamic Defenders Front), one of the 
Islamic organizations that put forward Amar Ma'ruf Nahi Mungkar, who always participated in raiding CSWs?

Ati replied that FPI was a good organization, he reasoned because actually the FPI wanted us to be good people. Inviting us prostitutes or prostitutes back to nature. The right path blessed by Allah Almighty. That answer also ended our interview that night. And we advised that he will receive guidance from Allah Almighty and be able to return to the right path. He also asked that we pray for him if he has a large enough capital, he wants to establish his own business rice shop.

The results of our observations on Monday night Tuesday May 6 2019, at 20:00 to 00:00 WIB in Sunan Kuning. Awalya we are confused because this Sunan Kuning signpost is written "during the month of rahmadan totally closed", the condition of this yellow sunan is different from the previous situation where this place was quiet like a complex in general, at first we thought it might not have been here but there was no result but ultimately we managed to interview a prostitute named Dewi (not her real name). The results of our interviews are as follows: Dewi is 21 years old, she is originally from Mojokerto, East Java, Dewi is a wife who has a husband and 4 yearold daughter. When asked about her family's response to the work she is currently experiencing, she says that her family only knows that she works without knowing what work Dewi does, parents of the goddess, including parents who depend on her and every month she has to support her parents, her husband and child.

The tariff he pegged to each customer is $\mathrm{Rp}$ 200,000 - Rp 250,000. and this Goddess can serve 1-15 customers in one night, the income that can be obtained by this Goddess ranges from $\mathrm{Rp}$. 2,000,000-Rp. 3,000,000 per night. Actually this job is not the will of the Goddess he was confused about how to boost the family economy, and Dewi also hopes that one day he can work with work that is in accordance with the will of God and can go home and gather with his family.

\section{F. Prostitution in Various Perspectives \\ 1. Sociological Perspective}

According to the theory of sociology, which was put forward by Prof., Dr. Rony Nitibaskara, about the concept that "every crime / deviant behavior has a function / duty in society where one of its functions is as a Balancing Tool" The point is that in every criminal act other than there is a party that is harmed, there are also parties who benefit from the crime. The practice of prostitution is indeed very contrary to normative norms and religious norms, but there are groups of people who benefit from the practice of prostitution, namely the people who live around the location of the practice of prostitution who are looking for livelihoods around the location of prostitution.

\section{Criminal Law Perspective}

Prostitution if we look at the Criminal Code (KUHP) then there is no single article that specifically regulates, so it is criminologically difficult to say that prostitution is a crime, because it does not cause casualties. In responding to this prostitution the law in various countries is different, there are categorized as delik (criminal acts), there are also those who are silent with some exceptions, including Indonesia being silent with exceptions. With regard to prostitution of the Criminal Code regulates it in two articles, namely article 296 and article 506. Article 296 states' who intentionally causes or facilitates obscene acts by others, and makes it a livelihood or habit, threatened with imprisonment no longer than one year and four months or a maximum fine of fifteen thousand rupiah. While article 506 states' whoever gains profit from the obscene acts of a woman and makes her a prostitute, is threatened with a maximum imprisonment of one year. From there we can know that our criminal law only categorizes prostitution as an offense against its intermediaries. With this reality law enforcement officers, in this case the Police only have space to take legal action against intermediaries, if there are intermediaries, to disclose this, the Police must be proactive by using its personnel to conduct investigations through intelligence tasks that have become separate institutions in the body parts of the Police

Other provisions that may be used in snaring the practice of prostitution are Law Number 21 of 2007, concerning Eradication of the Criminal Act of Trafficking in Persons and / or Law Number 23 of 2002, concerning Protection of Children, namely when involving children, or other legislation related to criminal law.

\section{Conclusion}

The background of the emergence of prostitution is caused by several factors, such as family economic factors, parental education factors, family 
environmental factors, and social environmental factors. Of the four factors that dominate the background of entering the world of prostitution, namely the weak family environment factors, due to lack of functioning and role of the family itself so that child informants are easily influenced into the world of prostitution.

The impact of this work risk that occurs in the form of violence, namely, psychological (mental) violence, physical violence, sexual violence. While the impact on health and misuse of illegal drugs was not found in this study. Based on the results of research on each informant it is known that violence in the form of psychic violence is the most commonly accepted violence, this violence is carried out both the people in their neighborhood and from consumers who are the services of the informants. Psychic violence experienced by the informant in the form of insults and curses that cause inferiority. Besides physical violence experienced by informants, namely kicks in the thighs, slaps, blows to the eyes, and hair in the hair. This violence occurs when the informant refuses the consumer's request to engage in sexual activities that are considered dangerous to the informant's life, such as engaging in oral sex and engaging in sexual activity through anal informants, which causes the child informant to eventually experience sexual violence as a result of coercion by that consumer, violence perpetrated by consumers as a form of sense of having power over informants who have no bargaining value to consumers.

In connection with the above conclusions, then there are some things that can be suggested by the authors and are expected to be used as material for consideration for parties related to this research:

1. Considering it was found that poisoning themselves with various factors underlying the causes in this study, it is considered necessary for guidance and education in accordance with the characteristics and personality of children. As parents must always monitor the child's development, including the social environment outside the home. Parents should be able to be a good example or example for their children and be able to provide wise solutions when children experience difficulties and problems so that children feel they have guidance and love, and provide a good and true religious provision, always instilled from an early age because religion is the basic capital and the best provision for children in the future
2. Considering the finding of those who prostitute themselves vulnerable to violence, there needs to be guidance for children, whether done from the family, community, social institutions, or the government to be able to reduce the number of children who prostitute themselves.

3. Seeing the conditions that researchers see and find in the field, suggesting readers, especially students of sociology to be more grateful for what they already have and can continue to college, because apparently there are still many nation's successors who are struggling to support and gain education by ways which makes it difficult for themselves, such as children in white and gray uniforms who work as commercial sex workers (CSWs).

\section{Declaration of Conflicting Interests}

The authors state that there is no potential conflict of interest in the research, authorship, and/or publication of this article

\section{Funding}

None

\section{References}

Al Yadainy, F. A. (2020). Surrogate Mother Agreement and the Effect on Children's Status Born. Journal of Law and Legal Reform, 1(2), 311-324. https://doi.org/10.15294/jllr.v1i2.35418

Andhini, A.S.D., \& Arifin, R. (2019). 'Analisis Perlindungan Hukum Terhadap Tindak Kekerasan pada Anak di Indonesia'. Ajudikasi: Jurnal IImu Hukum 3 (1), 41-52. http://dx.doi.org/10.30656/ajudikasi.v3i1.9 92

Anwar, Y., \& Adang, A. (2013). Kriminologi. Bandung: PT. Refika Aditama.

Arifin, R. (2020). Legal Services and Advocacy in the Industrial Revolution 4.0: Challenges and Problems in Indonesia. Indonesian Journal of Advocacy and Legal Services, 1(2), 159- 
162.

https://doi.org/10.15294/ijals.v1i2.36488

Caswanto, C. (2016). "Tindak Pidana Prostitusi yang Diusahakan dan Disediakan oleh Hotel di Indramayu dalam Perspektif Hukum Pidana Indonesia". Thesis, Universitas Pasundan.

Chusnafariha, N. (2017). "Cyber Prostitution Dalam Perspektif Hukum Islam dan Hukum Positif", Thesis, Universitas Islam Negeri Walisongo Semarang.

Erdianti, R. N., \& Al-Fatih, S. (2019). Fostering as an Alternative Sanction for Juveniles in the Perspective of Child Protection in Indonesia. JILS (Journal of Indonesian Legal Studies), 4(1), 119-128. https://doi.org/10.15294/jils.v4i01.29315

Gunawan, R., Mahendra, M. H., Zakaria, H. R., \& Qoyum, M. (2020). Behavior Motives and Legal Study of Commercial Sex Workers Around Pemalang District Terminal Area. Law Research Review Quarterly, 6(1), 53-68.

https://doi.org/10.15294/Irrq.v6i1.31214

Juliana, R. \& Arifin, R. (2019). 'Anak dan Kejahatan (Faktor Penyebab dan Perlindungan Hukum)'. Jurnal Selat 6 (2), 225-234. DOI: https://doi.org/10.31629/selat.v6i2.1019

Kartini, K. (2005). Patologi Sosial. Jakarta: Raja Grafindo Press.

Kemala Dewi, M., \& Arifin, R. (2019). Emancipation and Legal Justice; Portrait of Women's Legal Protection In Indonesia. Jurnal Cita Hukum, 7(1), 101-114. DOI: https://doi.org/10.15408/jch.v7i1.10261

Larasati, A. M., \& Ayu, N. P. (2020). The Education for Gender Equality and Human Rights in Indonesia: Contemporary Issues and Controversial Problems. The Indonesian Journal of International Clinical Legal Education, 2(1), 73-84. https://doi.org/10.15294/ijicle.v2i1.37321

Latifiani, D. (2019). The Darkest Phase for Family: Child Marriage Prevention and Its Complexity in Indonesia. JILS (Journal of Indonesian Legal Studies), 4(2), 241-258. https://doi.org/10.15294/jils.v4i2.34708

Munawaroh, S. (2010). Pekerja Seks Komersial (PSK) di Wilayah Prambanan, Kabupaten Klaten, Jawa Tengah, Pekerja Seks Komersial. DIMENSIA 4(2), 65-80.
Niravita, A. (2020). Social Injustice in the Industrial Revolution 4.0. Indonesian Journal of Advocacy and Legal Services, 1(2), 163-168. https://doi.org/10.15294/ijals.v1i2.36509

Nurdiana, M.A., \& Arifin, R. (2019). 'Tindak Pidana Pemerkosaan: Realitas Kasus dan Penegakan Hukumnya di Indonesia (Crime of Rape: Case Reality and Law Enforcement in Indonesia)'. Literasi Hukum 3 (1), 52-63. Retrieved from http://jurnal.untidar.ac.id/index.php/literas ihukum/article/view/1350

Putri, A.R.H., \& Arifin, R. (2019). 'Perlindungan Hukum Bagi Korban Tindak Pidana Perdagangan Orang di Indonesia (Legal Protection for Victims of Human Trafficking Crimes in Indonesia)'. Res Judicata 2 (1), 170-185. DOI: http://dx.doi.org/10.29406/rj.v2i1.1340

Oktavina, S. (2020). Population Growth Control Policy and Its Effect to Law Enforcement. Journal of Law and Legal Reform, 1(2), 225-240. https://doi.org/10.15294/jllr.v1i2.35460

Ralph, C.H. (1961). Women of the Street, A Sociological Study of Common Prostitute. London: Ace Books, Love \& Malcomson Ltd.

Rosana, E. (2011). Modernisasi dan Perubahan Sosial. Jurnal TAPIs 7(12), 15-38.

Setyaningrum, A., Arifin, R. (2019). Analisis Upaya Perlindungan dan Pemulihan Terhadap Korban Kekerasan dalam Rumah Tangga (KDRT) Khususnya Anak-Anak dan Perempuan. JURNAL MUQODDIMAH: Jurnal IImu Sosial, Politik dan Hummaniora 3 (1), 9-19. Retrieved from http://jurnal.umtapsel.ac.id/index.php/muqoddimah/article /view/677

Siregar, K., Pelly, U., \& Sadat, A. (2015). Model Pengaturan Hukum Tentang Pencegahan Tindak Prostitusi Berbasis Masyarakat Adat Dalihan Na Tolu, Perdana Mitra Handalan. Mimbar Hukum 28(3), 414-426, https://doi.org/10.22146/jmh.16676

Soekanto, S. (1994). Sosiologi Suatu Pengantar. Jakarta: Raja Grafindo Persada.

Susanto, J., \& Utari, I. S. (2020). Children as Victims of Sexual Violence Committed by Parents: A Criminological Perspective. Journal of Law 
and Legal Reform, 1(2), 353-363. https://doi.org/10.15294/jllr.v1i2.36007

Tamba, A. R., \& Masyhar, A. (2020). Protection of Victims of Domestic Violence (Study Decision Number: 2660/Pid.Sus/2015/PN Mdn). Journal of Law and Legal Reform, 1(2), 297-310. https://doi.org/10.15294/jllr.v1i2.36008

Wantu, F. M., \& Sarson, M. T. Z. (2020). Legal Protection of Women as Victim of Domestic Violence. Indonesian Journal of Advocacy and Legal Services, 1(2), 243-258. https://doi.org/10.15294/ijals.v1i2.36093

Wicaksono, A. A., Saefudin, Y. R., Ramadhan, H., Pangestu, R. A., \& Arifin, R. (2020).

Submitted June 29, 2019

Revision received April 23, 2020

Accepted April 30, 2020
Criminological Aspect on Case of Prostitution around Poncol Station Semarang. Law Research Review Quarterly, 6(1), 19-36. https://doi.org/10.15294/Irrq.v6i1.31099

Yudhanti, R., Arifin, S., \& Rismadini, F. (2017). The Protection to Victims of Violence Based on Gender as a Fulfillment of the Constitutional Rights in the Perspective of Human Rights in Boyolali's District, Indonesia. JILS (Journal of Indonesian Legal Studies), 2(1), 15-24. https://doi.org/10.15294/jils.v2i01.16638

\section{How to cite?}

Sagala, E., Sihotang, N., Efendi, Z., \& Febriyana, A. (2020). Prostitution as Social Pathology: A Legal and Criminological Perspective. Law Research Review Quarterly 6(2), 91-100. https://doi.org/10.15294/Irrq.v6i2.31109. 
Quote

We say that slavery has vanished from European civilization, but this is not true. Slavery still exists, but now it applies only to women and its name is prostitution.

VICTOR HUGO, Les Misérables 